\title{
Membership in the digital era
}

\author{
Swedish trade unions' use of Internet and social media
}

\begin{abstract}
The aim of the article is to explore trade unions' use of Internet and social media in communicating with members and to understand membership in the digital era. A point of departure is that new forms of relationships between individuals and organizations are on the rise as our present societies become more digitalized, which has changed how citizens interact, mobilize, and organize. Digitalization has been discussed as a driving factor behind membership decline and disengagement, but also as an opportunity to revitalize the labor movement. Drawing on theories on social movements, interest groups, and civil society organizations the article adopts a multi-dimensional perspective that understands membership as participation, resource, representativeness, and identity. It presents results from a qualitative study of two Swedish trade unions. The empirical data consists of documentation from websites and social media complemented by interviews with employees with knowledge about the unions' Internet and social media communication. The results show that Swedish unions do not seem to be adapting to new technologies, rather using them as opportunities for strengthening and reviving membership without re-formulating its premises.
\end{abstract}

Keywords: membership, trade unions, civil society, social media, Sweden

THE AIM OF this article is to explore trade unions' use of Internet and social media in communicating with members and to understand membership in the digital era. The article draws on theoretical perspectives on membership in social movements, interest groups, and civil society organizations. A point of departure is that new forms of relationships between individuals and organizations are on the rise as our present societies become more digitalized (Shirky 2008). Digitalization allegedly has changed how citizens interact, mobilize, and organize, and thus it challenges our understanding of membership. However, previous research on digitalization has seldom focused on membership as organizational feature. In line with much sociological literature on membership in organizations (e.g. Ahrne 1994; Ahrne \& Brunsson 2011) we understand membership as a relationship between organizations and individuals that entail rights and duties. This relationship however entails different aspects, for instance depending on its locus of definition (e.g. individual, organizational, or institutional). Hence we argue for the need of a multi-dimensional approach to membership that highlights different aspects of the relationship between organizations and individuals 
- as resource, representativeness, participation, and identity (these will be discussed further in "A multi-dimensional perspective on membership").

The assumption is often that digitalization has produced considerable challenges for formal organizations whether in social movements, interest groups, or civil society and hence for traditional forms of collective action. Some research suggests, for instance, that formal associations (i.e. formal organizations in civil society based on membership of individuals or organizations) as an organizational form have lost much of their significance and perhaps their dominant position in favor of looser, temporary, and network-based forms of organizing on social media (Bennett \& Segerberg 2012, 2013; Scaramuzzino 2014; Shirky 2008) with a different logic of membership (Scaramuzzino 2017). The associational form of organizing is particularly dependent on membership. Especially for associations representing societal groups according to a self-organizing logic, membership becomes an important resource on which they draw their legitimacy. Hence this article draws on a qualitative study of two cases of associations in the Swedish labor movement. The article focuses on membership as a relationship between organizations and individuals and aims at answering the following two research questions:

1. How and why do the trade unions use the Internet and social media in communicating and interacting with their members?

2. How can the relationship between organizations and individuals (as it unfolds on the Internet and social media) be understood as membership from a multidimensional perspective?

Trade unions are chosen as cases as union membership often plays an important role for these associations, in particular in Sweden. Membership in fact defines these organizations' power in bargaining and the potential effectiveness of many of the strategies in their repertoire, including street protests and strikes. Trade unions are often considered part of one of the first social movements, the labor movement (Fantasia, Voss \& Eidlin 2013), and they were already at the beginning of the 20th century described as tending towards organization, centralization, and bureaucratization (e.g. Michels 2001[1911]). They have through the years become increasingly institutionalized and have in many countries held close relationships with political parties and public authorities.

Since the end of the "golden age of collective bargaining" in the 1980s and 1990s, unions have lost a great deal of power and many of their members in most Western countries (Bengtsson 2013; Björkman \& Huzzard 2005; Bryson, Gomez \& Willman 2010; Einarsson 2011; Gumbrell-McCormick \& Hyman 2013; Kjellberg 2011; Köhler \& Calleja Jiménez 2012; Palm 2017; Voss \& Sherman 2000; Ward \& Lusoli 2003). It is debated to what extent this decline might be a consequence of digitalization, and many scholars suggest that the decline of trade union membership can be traced back to before the introduction of new information and communication technologies (Movitz \& Sandberg 2019; Kjellberg 2019). The degree of decline seems to have varied between countries and over time within countries (Palm 2017), but only few trade 
union movements have been able to successfully maintain their membership levels or restore them to those of the 1970s (Waddington 2015; Western 1995). This tendency of declining membership has sparked a debate throughout Europe and many other Western countries, with some authors questioning the significance of trade unionism for the 21 st century and the future role of such organizations (Boeri, Brugiavini \& Calmfors 2001; Hyman 2004).

The next section presents an overview of research on trade unionism, membership, and digitalization followed by a presentation of our theoretical framework: a multidimensional perspective on membership. After that is a presentation and discussion of case selection and methodology. Then comes the presentation and analysis of the findings structured around the four dimensions of membership. The concluding section discusses the findings in relation to the concept of membership and to processes of digitalization.

\section{Previous research on trade unionism, membership, and digitalization}

There is extensive research on trade unionism, membership, and digitalization and three strands can be identified. A first relevant strand of research has examined the impact of Internet and social media on trade unions and to what extent they have been transformed by new technology (e.g. Greer 2002; Diamond \& Freeman 2002; Chaison 2005; Stevens \& Greer 2005; Panagiotopoulos 2012; Panagiotopoulos \& Barnett 2015; Schradie 2015; Sipp 2016). The impact of Internet and social media on unions is an issue of debate. Some have argued that unions generally have been slow to adapt to digital media (Sipp 2016) while others have shown the opposite (Diamond \& Freeman 2002). Research indicates however that most of the trade unions in Western countries use Internet and social media even if there are differences both within countries and between countries (Rego et al. 2014). Over the last few years the number of available digital communication channels have increased and today many unions use Twitter, Facebook, YouTube, LinkedIn, etc. (Panagiotopoulos \& Barnett 2015). Large unions tend to be more active on social media as it is resource demanding to run an effective website and manage other communication channels. Research indicates that there are a few key players who are growing stronger and that smaller unions with fewer resources are being left behind (cf. Ward \& Lusoli 2003; Panagiotopoulos \& Barnett 2015; see also Scaramuzzino 2017). Scholars have expressed concern that if the unions fail to exploit the opportunities social media offer to attract members, new organizations or other types of organizations might provide services to workers online instead (cf. Voss \& Sherman 2000; Diamond \& Freeman 2002).

A second strand of research has focused on union membership from an organizational perspective. For example, Nicholas Solebello, Mary Tscjrhart and Jeffrey Leiter (2016) have focused on the paradox of inclusion and exclusion in trade unions and how it can create problems when it comes to membership. Accordingly, unions often want to broaden their membership base and make several attempts to become more inclusive through 
different "diversity initiatives". However, the leaders' attempts to increase the trade unions' inclusiveness are often met with wishes to maintain the trade unions' exclusiveness. If the members become more diverse it can create challenges related to the union's identity and it can be difficult to re-define who the union members are. The leaders within the trade union may attempt to manage the paradox between inclusion and exclusion by using strategies that both legitimize the diversity initiatives and that change the identity and culture. Another study (Frangi \& Barisione 2015) highlighted so-called "subjective union membership" as opposed to "objective union membership". Unlike objective union membership, subjective membership takes into account the members' own awareness of being affiliated to a trade union. There are also studies (e.g. Strøby Jensen 2017) that focus on political attitudes and if they influence the likelihood of being a union member. The results differ between countries. For example, left-wing political attitudes had more impact on the likelihood of union membership in Sweden than in Denmark. Thus, the overall impact of left-wing political attitudes on unionization in these countries reflects the fact that trade unions are "normative organizations". Johanna Palm (2017) has also studied what mechanisms affect the individual inclination to join a union by focusing on class background, class identity, and ideology.

A third strand of research has focused on associational membership in itself. Research within this strand has mainly focused on the difference between passive and active membership (Hvenmark 2008; Minkoff 2016). Passive membership implies that the individual only pays membership fees and supports the organization's ideas. To be regarded as active membership, the individual also needs to, on a voluntary basis, attend meetings, act as a representative for the organization, write articles, participate in demonstrations, and so on (Hvenmark 2008). There are also studies (e.g. MackerleBixa, Meyer \& Strunk 2009) that have focused on the relationship between formal membership, participation, and political engagement. Accordingly, organizations that only foster broad membership do not necessarily contribute to citizens' participation and engagement. It is hence a challenge for organizations that rely on members' engagement, to find ways to turn passive members into active members (Mackerle-Bixa et al. 2009). However, some studies show that organizational membership seems to increase the levels of political action among both active and passive members (Minkoff 2016).

Some researchers have instead raised the question of whether we need to reconsider the nature of union membership in the digital era, beyond formal membership (Diamond \& Freeman 2002; Karpf 2012; Panagiotopoulos \& Barnett 2015). Research has highlighted how digitalization enables activists to sidestep union hierarchies and how groups of workers have created grassroots websites, e-mail lists, and Facebookpages in order to have a collective voice (Diamond and Freeman 2002; Chaison 2005; Scaramuzzino \& Meeuwisse 2019). David Karpf's (2012) study shows, for instance, how the Internet and social media have played an important role in challenging the notion of membership and broadened its meaning. People who do not pay membership fees can still be regarded as "members" because likes and followers on social media are considered valuable for organizations regardless of how responsive the "members" are. By only sending one message, organizations can reach all their followers. These "mem- 
bers" can be mobilized when needed with hardly any transaction costs at all. However, such members tend to be anonymous, which makes it difficult to determine how many workers these organizations actually represent (Scaramuzzino 2017). Organizations can, however, use "clickthroughs" on social media to identify both low-activity and high-activity "members" (Scaramuzzino 2017), and in this sense digitalization might not only represent a challenge for the organization and mobilization of workers, but also an opportunity to turn the trend and revitalize the labor movement.

\section{A multi-dimensional perspective on membership}

Membership in associations can be understood as a particular form of relationship between organizations and individuals (see also Einarsson 2012; Hvenmark 2008). In this section, we will explore four dimensions of relations between unions and members based on previous research from three fields - social movement, interest groups, and civil society studies. Trade unions are relevant to all three research fields and the dimensions can partly be related to what has been described as the "sources of union power", i.e. structural, organizational, institutional, and societal (Lehndorff, Dribbusch \& Schulten 2017). While the four dimensions are presented as distinct, they are in practice interrelated and partly overlapping, which is confirmed in our findings.

The first perspective understands membership as a resource. This perspective draws mainly on the social movement literature, which has mostly neglected and avoided the concept of membership. This is partly due to the fact that social movements are only partly organized. Social movements, however, tend to spawn so-called social movement organizations that can be defined as organizations that identify with the goals of a social movement and attempt to implement these goals (McCarthy \& Zald 1977). Trade unions are often seen as an example of social movement organization within the labor movement together with political parties and works councils (Fantasia et al. 2013). To grasp the relationship between individuals and organizations, concepts such as "collective action" have been central to this research field (Oliver 2013) emphasizing the episodic and interactional feature of social movements (Tilly 1984). From a social movement theory perspective, "membership implies very different levels of organizational involvement in different [social movement organizations]" (McCarthy \& Zald 1977:1227). To grasp the intensity of involvement, other concepts have been used, such as adherents for those who identify with the goals of the organizations and constituents for those who provide the organization with resources (McCarthy \& Zald 1977). This approach focuses on the organizational level and highlights membership as a resource for the organization that can be mobilized as a means to gain influence.

The second perspective understands membership as representativeness. This perspective draws on both civil society and interest group research and relates to the so-called "numbers game" (Casey 2004). This means that an organization that can claim to represent many members, to be able to influence voters, or to get people to demonstrate can also claim to have power. This is relevant in particular for trade unions when it comes to collective bargaining and the call for strikes. This power, 
however, is dependent on the level of "coverage" of the potential membership base (Casey 2004). Representativeness is not a function of how many members an organization represents, but rather of the share of the total population that an organization can claim to represent. Representativeness in this sense is closely linked to legitimacy and can, accordingly, "... be used relatively cheaply at several levels of governance at the same time" (Dür \& Mateo 2012). Here the focus is on the institutional level and representativeness is related to the expectations that many public authorities have of civil society organizations to be representative in order to interact with them, something that by extension legitimizes public policies as well (Klüver 2010).

The third perspective understands membership as participation. Much research has been focused on measuring voluntary association membership (sometimes understood as activity) in different national contexts (Baer 2007; see also Putnam 2001). The tension between membership and participation is clearly understood as the divide between "nominal" membership and "active" membership (Baer et al. 2001) and an assumption that "active" membership is "... probably more important from the standpoint of theoretical concerns about civic engagement and participation" (Baer 2007:72). Nominal membership per se, understood as mere (potentially passive) affiliation, has been considered less valuable from a societal point of view. For trade unions it means having members that are prepared, for instance, to assume representative positions, recruit other members, or participate in demonstrations and strikes. From this theoretical perspective, the focus is on the individual level and the way in which voluntary organizations mobilize and organize participation.

The fourth perspective understands membership as identity. While membership as resource, representativeness, and participation presupposes a more strategic approach, social movement research has also turned to more cognitive understandings of collective action focusing on the role of identity and identification. These strands of research are extensive (van Stekelenburg 2013) and cannot be fully presented here. What is relevant for our discussion on membership is that being a member of an organization provides the individual with a collective identity through group identification. Membership in a social movement organization is often related to a strong sense of identification because group membership is acquired (i.e. voluntary) rather than ascribed (non-voluntary). Membership in an organization for a particular category (e.g. workers) thus underscores a person's identification with that category (Klandermans $\&$ De Weerd 2000). One could say that identification with a collective identity and/ or a particular view or mission is often a precondition for membership and participation in a social movement and its organizations. However, such membership often also implies participation in a collective process of identification that influences the individual members' identities. Identity is thus both a precursor and a product of collective action (Hunt $\&$ Benford 2007). The decision to join a trade union, for instance, is partly based on identification with the collective identity of the workers the union represents. As a member, however, one becomes part of the continuous process of collective identity construction and negotiation, which in turn influences one's individual identity (van Stekelenburg 2013). 
Drawing on this literature, we distinguish four ways $f$ understanding membership in associations defined as relationship between individuals and organizations, as summarized in Table 1.

Table 1. Four dimensions of membership

\begin{tabular}{lll} 
Membership as & Locus of definition & Related concepts \\
\hline Resource & Organizational & Adherents and constituents \\
Representativeness & Institutional & Numbers game and legitimacy \\
Participation & Individual & Nominal and active membership \\
Identity & Cognitive & Collective and individual identity \\
\hline
\end{tabular}

This short overview gives us different insights into the meanings and functions of membership. In the concluding part of the article, we will come back to this theoretical framework and its contribution to our understanding of membership in the digital era.

\section{Case selection}

Sweden as a national context is known for its high use of the Internet, and it is one of the most digitalized countries in the world. It is also known for a civil society dominated by associations, membership organizations where member activities are highly valued and "the measure of success and influence is a large body of members and widespread participation" (Lundström \& Svedberg 2003:224). Trade unions have often relied on large memberships, hierarchical structures, and close affiliations with politicians and political institutions (Bengtsson 2013). Still having one of the world's highest degrees of membership amongst the employed population - in 2008, more than 70 percent of workers (Kjellberg 2009:267) - Swedish trade unions have long been a central actor representing workers and employees and have influenced many of the social and economic policies in Sweden.

The two cases studied, IF Metall and Akademikerförbundet SSR, are trade unions that represent and organize industrial workers and academics with a degree in social science, behavioral science, or social work, respectively. The two cases are both membership-based associations that are well established and embedded in the Swedish corporative system of interest representation. For these unions, digitalization might be a challenge for their position of having a near monopoly on representing workers' rights, but also an opportunity for revitalizing their relationship with the members.

The two trade unions have followed different patterns of mobilizing and organizing. Industrial workers began to found trade unions over a century ago, and today IF Metall includes approximately 313,000 members, mostly employed in the private sector (IF Metall 2017). IF Metall represents blue-collar workers. Because of the increased internationalization and structural changes in the labor market, blue-collar workers 
have recently been struck by relatively high levels of unemployment, and IF Metall has experienced declining membership figures (Kjellberg 2011; see also Palm 2017). Akademikerförbundet SSR was founded in the late 1950s and is part of a later wave of labor organizations. It organizes approximately 71,000 members, mostly employed in the public sector (Akademikerförbundet SSR 2017). The union represents whitecollar workers, a group with low levels of unemployment. The number of members in the union has been constantly increasing, not least because the union has broadened its target group from social workers to academics with a degree in social science, behavioral science, or social work (cf. Scaramuzzino 2017).

IF Metall is hence a larger union when it comes to number of members but the membership base has been declining, while Akademikerförbundet SSR is a smaller union that has experienced a constant expansion of its membership base. Almost all members of Akademikerförbundet SSR have a university degree and they are all employed in the welfare system. Hence, this union not only represents the interests of welfare workers but also of social workers as a profession (Scaramuzzino 2017). Members of IF Metall are mostly employed in industry and in particular in plastics, pharmaceutical, construction, steel, chemical, and engineering industries. They have a strong link with the ruling Social Democratic Party and the current prime minister has been chairman of the union (Gumbrell-McCormick \& Hyman 2013; Johansson \& Scaramuzzino 2019).

These differences when it comes to membership trends, collective identities, and employment sectors, motivate a comparison between the two cases as these differences might influence the way in which the unions use the Internet and social media in communicating with members. The comparison can contribute to advancing our understanding of membership in the digital era. In the concluding part we will also discuss to what extent the findings might be generalizable to other organizations in civil society.

\section{Methods}

This research is based on a netnographic study, which encompasses specific procedures for how to conduct observations on Internet and social media, for interviewing and for analyzing the empirical material (Kozinets 2010). This method has been used to observe communication and interaction between each organization, its members, and the general public on Internet and social media. The observations were carried out between January 2016 and November 2017. During this period, we systematically observed the two unions in their online-activities. Hence, the bulk of data that this article is based on consists mainly of documentation from the two unions' websites and social media channels. At the time of the study, each trade union had a website, several Facebook pages, Twitter accounts, and Instagram accounts, and were present on YouTube and LinkedIn. IF Metall and Akademikerförbundet SSR posted on their social media channels almost every day, sometimes several times a day, to provide a constant flow of information and to interact with their members. However, the information about membership on the websites was rarely updated. Akademikerförbundet SSR updated 
the information more often than IF Metall. Both unions had communication departments with employees working with the union's websites and social media channels.

To get a deeper understanding of the observational data, it was complemented by four qualitative interviews, two for each trade union, with employees with knowledge about the unions' Internet and social media communication. The interviews were conducted between September and October 2016 and followed-up between May and August 2017, to be able to grasp changes and ask questions derived from our observations on Internet and social media. The two interviewees from IF Metall stated that they did not have much to add since the first interview. The interviewees from Akademikerförbundet SSR described a development in which they had started working more with films on social media, produced two Podcasts, and begun developing an application for recruiting members.

After all the empirical material was gathered, the whole data set was read several times. In order to limit the large data set, we only included membership-related content in our analysis. We then completed a deductive qualitative analysis relating the communication and interaction to our four dimensions: resource, representativeness, participation, and identity. While the multi-dimensional model captured the empirical material very well, and nothing had to be left out, it was sometimes difficult to categorize the empirical material into one dimension or the other, because some of the data could be placed in several dimensions as these were clearly overlapping in some parts. We will further discuss this in the concluding part of the article.

After categorizing the data, we searched for themes and did a comparative analysis looking at similarities and differences between the two trade unions' use of Internet and social media in communicating with members. This analysis is presented in four separate sections.

All content in Swedish in the quotations has been translated into English and deidentified in accordance with the ethical approval of the study.

\section{Membership as a resource: membership fees for services}

Membership as a resource can be understood as individuals' mobilization being a resource for the organization. To mobilize resources, the organization needs to convince those who identify with the goals of the organization, the adherents, to become constituents, i.e. those who provide the organization with resources.

Members are clearly a resource for the two trade unions for which the membership fees are an important source of funding. In fact, among Swedish interest organizations, unions are the ones that least rely on public funding (Scaramuzzino \& Wennerhag 2013). To convince adherents to become constituents and hence (paying) members, the unions need to show what services and benefits are entailed with membership. For this purpose, both unions used their social media channels. Recruiting members was thus central in the trade unions' activities on the Internet and social media. Both trade unions had staff that worked especially with recruiting new members. Recruitment seemed to be going on almost continuously, but there were also special recruitment campaigns. 
IF Metall had a lot of information about membership, especially about services and benefits, on its website. It wrote that as a union member you got access to many more benefits than those that were provided by the collective agreement and by law. As a member, you could get education within the union, insurances, and financial protection in case of unemployment or during strikes or lockouts. As a member you also got a union membership card that gave discounts and offers ranging from travels (like vacation cottages), wellness, and electronics to theater tickets and hairdressing services. You also got a subscription to the union's magazine and access to member loans, legal aid, and members-only pages on the website.

IF Metall also arranged competitions where members for example were asked to write why it was important to be a union member and what they considered as valuable member benefits. The winner got an iPad Air 2. The member that won the competition wrote: "A union membership gives me security, safety and a sense of belonging. The willingness to unite for a better future" (IF Metall Facebook 20 December 2016). There was also an animated video on YouTube which was launched the 4th October 2013 called "If the unions did not exist" addressing the importance of unions.

IF Metall had a campaign called "Members recruiting members" (see for example IF Metall website 28 January 2016 and 15 March 2017) that was advertised on both their website and their Facebook page. However, one of the interviewees argued that the Internet and social media had not primarily been used for these recruitment campaigns: "We usually speak proudly about member recruitment being done face to face" (Interviewee 1).

Akademikerförbundet SSR also wrote on their website about what was included in the membership. Just like IF Metall, they had a long list of different services and benefits that were "tailored to your needs". Akademikerförbundet SSR's message to its members was that as a member you could get advice and support from the union's specialists on issues like pensions, insurance, and issues concerning your professional role. Here we find a reference to the fact that Akademikerförbundet SSR was not only representing welfare workers but also social workers as a profession and hence addressed issues such as professional mandate and ethics in social work (cf. Scaramuzzino 2017). They also occasionally advertised on Facebook their houses and apartments that the members could rent: "On a hill in French Cagnes-sur-Mer you can stay in one of our Provençal houses with views of mountains and sea. By car you can easily drive between scenic beaches, charming mountain villages, towns and museums. You who are a member of Akademikerförbundet SSR can book easily via the link" (Akademikerförbundet SSR Facebook 18 March 2017). They also showed pictures from so called "members' nights" that they arranged (Akademikerförbundet SSR Facebook 16 November 2017).

The potential of using the Internet and social media for member recruitment is evident within Akademikerförbundet SSR, which had a campaign called "Together we grow" (Akademikerförbundet SSR, YouTube and website 8-9 February 2017) and had created material and tools available online that individual members and local associations could use for recruiting, including an application available both for iOS and Android. The two interviewees from Akademikerförbundet SSR also stated that 
representatives of the union were often on university campuses and at workplaces talking to people about joining the union. They also wrote about being successful in recruiting new members: "Now we are 70,000 strong. 70,000 well-educated, engaged and important members. Imagine what all these heads and hearts can accomplish together. Together we can make a difference" (Akademikerförbundet SSR Facebook 14 September 2017) and they posted a video with fireworks.

The similarities between the two unions are perhaps more striking than the differences. We can however see in our empirical material that IF Metall put more effort than Akademikerförbundet SSR in arguing for the importance of union membership. This emphasis in their Internet and social media activities might be connected to the union's recent loss of members. When it comes to recruiting members, Internet and social media seem to play a more important role for Akademikerförbundet SSR than for IF Metall. This might be related to the fact that the adherents of Akademikerförbundet SSR often have access to the Internet and social media in their everyday work while industrial workers are more easily addressed face to face at the workplace.

Both organizations implicitly stated that members were expected to contribute to the organizations by paying their fees. Here the relational dimension of membership becomes clear because the organizations need to present themselves as a resource for the individuals in order to motivate them to become members and thus contribute to the organizations. For this purpose, the Internet and social media seem to be frequently used communication channels.

\section{Membership as representativeness: hierarchical structures and two-way communication}

Membership as representativeness relates to the so-called "numbers game". Accordingly, an organization needs to be able, through a large membership base, to claim to represent a specific group and to be a legitimate advocate for that group's rights.

Digitalization offers new ways of counting members (Scaramuzzino 2017). Especially on social media, the number of likes and followers can be seen as part of the numbers game. The trade unions have many local associations, and therefore they also have several Facebook pages and Twitter accounts. For example, we found that as of 31 August 2017, IF Metall had 43 different pages on Facebook with everything from 5 to 21,176 likes and had 6,378 followers on Twitter. Akademikerförbundet SSR had 33 different pages on Facebook with everything from 10 to 6,138 likes and had 3,838 followers on Twitter. Because the unions have a relatively stable and transparent membership base and these figures are much smaller than the number of actual formal members, they might not provide an accurate measurement of representativeness. Instead, they might be seen as a sign that the organization had been successful in communicating through social media.

The importance of representing workers was emphasized by the two trade unions. Here it becomes clear that membership is a relational concept because representativeness is not merely an issue of the size and density of the membership base, but 
also of procedures for channeling the voices of the individual members. IF Metall and Akademikerförbundet SSR had complex systems for representation according to their websites, which are based on being represented at the workplace, but also at the unions' annual congresses where the most important decisions for the unions' futures are taken. They also have spokespersons at different administrative levels that are expected to speak for the organizations. In addition, the unions have national chairs that are the primary spokespersons and were often visible on the websites and social media channels.

Concerning representation, both unions seem to use Internet and social media to a large extent. However, managing communication through social media requires expertise, and the unions had professional communicators working on these channels often in real time and signing with their own names to make the communication more personal. The professional communicators' role was thus to speak for the union on social media, to meet the many voices of the members, and to channel their concerns upwards in the organization. Because these are often not elected spokespersons, the extent to which the content communicated is rooted in a democratic decision-making process is crucial for their representativeness in times when the forums for representation are changing due to digitalization.

IF Metall used Internet and social media to highlight that the union was a support for all its members. As a response to the experiences of harassments highlighted by the Metoo-movement, the union stated that all workers regardless of age and gender should feel safe and welcome to their jobs in the industry (IF Metall Twitter 21 November 2017). On this topic, IF Metall also highlighted the role of its representatives and spokespersons through statements that representatives should be the obvious contact for members that needed support with a clear reference to LGBT-issues (IF Metall Twitter 6 July 2017). When it came to the representatives, there was also a need to show different "faces" depending on the target groups of the communication, according to an interviewee from IF Metall, so that all the members felt represented. This could also be a challenge for the unions due to established governance structures. While stressing the importance of being present in workplaces and having a face to face dialog with members, one interviewee from IF Metall argued that social media had a positive influence on representativeness because it allowed two-way communication with the members and potential members.

Akademikerförbundet SSR emphasized the role of the elected representatives and described them on their webpage as the face of the union, the extended arms of the members, and the link between the local association and the union. The importance of representativeness was highlighted in the statement, "Together we are stronger" (Akademikerförbundet SSR website 25 February 2017). One interviewee said that it was important that the members felt that the union was "easy to reach and accessible" (Interviewee 3) and the national federation was "close" to them, knowing the staff by name.

When it comes to representativeness, we find a pattern of a stronger engagement of IF Metall to communicate with its members through Internet and social media, com- 
pared to Akademikerförbundet SSR. This might be partly related to the membership loss, which can be interpreted as a legitimacy crisis that needs to be handled through communication. It might also be related to the need of handling the identity and value conflicts that characterized this union as will be addressed later.

\section{Membership as participation: selling insurance policies and the free rider dilemma}

Membership as participation draws on the distinction between "nominal" and "active" membership and an assumption that "active" membership is more valuable from a societal point of view.

Both trade unions stress that it is essential for them to convince nominal members to become active members. On the Internet and social media, they wrote about how members could engage in and participate within the union. They emphasized that to be a union member was not just about services and benefits and signing insurance policies against unemployment, it was about participating and engaging for workers' rights. Communication seemed to play a key role here as interviewees from both IF Metall and Akademikerförbundet SSR stated that it was important for them to create a relation with their members online. Thus they not only wanted to use social media like Facebook to send information, they also wanted to create two-way communication to foster engagement and participation.

For instance, IF Metall wrote on their website: "As a member of IF Metall, you do not just buy an insurance policy, you also become part of one of the world's strongest popular movements. How and what the union will work with is based on the members' wishes and participation." (IF Metall website, 25 April 2016). An interviewee from IF Metall said, "We publish a little more of what we know activates people on social channels," and "I do not really want to have stuff on Facebook that does not create engagement." (Interviewee 2). The same interviewee continued: "We need to rethink how we publish. What is most important? That they get the message or that it is published in the form that we are accustomed to?" (Interviewee 2). Adapting the communication strategy and the message to the Internet and social media and to the target groups' preferences had been discussed within the union and had proven to be a sensitive and contentious issue. To foster participation, it was important to find the right "tonality", according to the other interviewee from IF Metall.

Promoting participation takes time and requires a lot of knowledge on how the new Internet-based technologies work. Unions needed, according to one of the interviewees from Akademikerförbundet SSR, to stay updated on the algorithms that govern the flow on social media, for instance, on Facebook. To achieve a constant flow of content, they needed to publish the right type of material (e.g. using videos on Facebook) on the right issues to attract attention and ensure that traffic stayed on the organizations' website and social media channels. Knowledge about the issues that foster engagement within the union's target group could also be obtained by following the use of Internet and social media. According to one of the interviewees from Akademikerförbundet 
SSR, through different "watch lists" they could see what people were engaging in and discussing in real time, and thus they could pick up on important issues for their social media channels.

The distinction between recruiting members and organizing them (see also Lehndorff, Dribbusch \& Schulten 2017) was emphasized by one of the interviewees from Akademikerförbundet SSR. "I think words make a difference (...) To recruit, yes, of course, you can do that. But to organize, then you actually become part of something in which you are an active part" (Interviewee 4). This might be interpreted as an expression of a distinction between membership as a resource and membership as participation, challenging the idea that recruiting nominal members is sufficient. For members to become a true resource, you need to organize them in the sense of making them become active members as well.

The unions seem to be able to use the Internet and social media to foster participation. It seems however that communication through Internet and social media is more often used for presenting the union as a resource for the members rather than for fostering members' participation and engagement beyond passive membership.

\section{Membership as identity}

Membership as identity draws on the collective identity provided by the organization through group identification. Membership in this sense implies participation in a collective process of identification that influences the single members' individual identities.

Membership as identity also plays an important role on the Internet and in social media. It is, for instance, obvious that while the trade unions try to recruit as many members as possible, not everyone can be a union member. There is a collective identity linked to being part of the specific group that is to be represented, whether it is industrial workers or academics, and on the unions' websites there was information about who could apply for membership.

There is a strong connection between identity and common interest as emphasized in the following from IF Metall's website:

The trade union is a union for you who are a wage earner. Together we are strong and can defend our rights against employers. In the union, we agree on the salary and conditions we will require for our work and we make it clear that none of us will work for less. We call it the union promise. Without the promise, there is a negative competition in the labor market - if you lower your salary, I have to lower mine to keep my job, and so on. (IF Metall website 25 April 2016).

As the quote shows, the unions often wrote "we" and "us" to provide a sense of belonging and collective identity. IF Metall also wrote that the members together are IF Metall. Furthermore, they often stated that their members were not only part of a strong trade union, they were also part of the labor movement - one of the largest 
popular movements in Sweden together with the organizations linked to the Social Democratic Party.

The social-democratic identity that had been institutionalized in the industrial workers' trade unions for more than a century had sparked a major conflict that was made more visible by social media. Many of IF Metall's values and much of its identity are intertwined with the Social Democratic Party, while many of their members vote for other parties. A clear sign of this conflict was that, on their Facebook page, some members often criticized the union for supporting and giving money to the Social Democrats and their election campaigns. Perhaps the most visible conflict was with those members who sympathized with and/or voted for the Sweden Democrats, a nationalistic, right-wing party with a socially conservative and anti-immigration agenda.

Both interviewees from IF Metall acknowledged this conflict. One of them described it both as a problem and as an opportunity for the union to actually show people and their members what the union stood for. Social media forced them to become more transparent and to take a clear stand. In fact, both on their website and on social media, IF Metall stated, "The Sweden Democrats' values collide with IF Metall's values."

This conflict could be understood as a clash between the institutionalized collective identity of the union and the individual identities of a significant number of its members. This discussion became even more pressing when it came to the elected representatives. It was clear that IF Metall excluded the possibility that a representative could be elected if he or she sympathized with the Sweden Democrats. On the union's website, it was stated that the mission was to defend all workers' rights against employers and that dividing workers based on culture, ethnicity, or skin color went against this mission (see also "Different together: handbook for diversity" 13 April 2015). On its website, Facebook, and Twitter, the union also stated that the Sweden Democrats were against everything that the Swedish model stood for - equality, strong unions, and strong welfare.

When the union expressed these opinions on social media channels, they often sparked debate and criticism from some of the members, to whom they needed to respond. For example, one member wrote a comment on Facebook: "The union should not interfere in what political party the members vote for! Instead, do your job!" (IF Metall Facebook 12 October 2017). A communicator responded:

Hey (first name), we do not interfere in the members' voting. That is up to everyone to decide but the union has an obligation to inform how the politics affect our members. Some issues are difficult to pursue and influence through negotiations with the employers, such as healthcare and childcare. Therefore the union considers as its duty to be politically active in the interest of its members. If we do not participate, there will always be someone else who does. The employers actively pursue political influence of their own and it would never come to their mind to stop trying to influence. Sincerely (first name)/Communication (IF Metall Facebook 12 October 2017). 
This political stand did not seem to be negotiable, and a communicator on the union's Facebook-page responded to a member: "...If you want to leave the union, you will find information on how to do so on our website. I would still recommend you to speak with a union representative at your local chapter in advance in order to get the whole picture and to understand how the union works. Sincerely (first name)/Communication" (IF Metall Facebook 13 October 2016).

This shows that while IF Metall represented its members, it also had a strong and institutionalized collective identity and there were certain values that the members needed to agree on in order to be members.

Because social media allows for open communication between the union and its members, individual members' identities are potentially made more visible, something that might challenge the collective identity. This conflict was most visible within IF Metall and can be related to a general identity crisis of the labor movement in a postindustrial society.

It is clear that social media allows the unions to get in touch with a larger portion of the population and with more potential members. One of the biggest challenges the unions face is to find the right way to approach people so that they feel that the information is interesting and relevant for them. New technology seems to both require and allow the unions to divide their members into different target groups. "We are talking a lot about target groups nowadays" as expressed by an interviewee from IF Metall (Interviewee 1). Measuring the use of communication channels and getting statistics on the flows of communication thus becomes essential.

According to one of the interviewees from Akademikerförbundet SSR, in the union there was also much more talk about different target groups today and how to approach them in a way that served the members. This was particularly evident for this union whose traditional membership base had been broadened from social workers to all academics working in the welfare sector, a heterogeneous group when it comes to employers, education, working conditions, and professional identity. Thus it was important for the union to make all target groups feel included and welcome, according to one of the interviewees. Sometimes this required a fine balance when publishing material that needed to be relevant for as many groups as possible, according to one of the interviewees: "Some issues, like working environment, physical health and so on, are those that most academics find important. However, there are also specific issues. If we talk about the social services, it is interesting for those who work within the social services. If we talk about schools, it is interesting for those who work as school counselors. I think that one always has to decide. What issues need to be addressed?" (Interviewee 3). To handle this fine balance and finding issues that the different target groups have in common is hence essential to create a collective identity.

Both unions studied here struggled in different ways to handle strong institutionalized collective identities, on the one hand, and their members' individual identities, on the other; something that seems to become prominent in the direct interaction between the unions and their members on social media. 


\section{Conclusions and discussion}

The findings of this study highlight that Swedish trade unions use Internet and social media to a large extent and that much effort is put into communicating with present or potential members. The four dimensions of membership discussed have helped us disentangle how membership unfolds in the communication and interaction between unions and members on the Internet and social media. Our theoretical framework has hence allowed us to understand membership in the digital era from a multi-dimensional perspective. However, our model has proven to be one-sided in its understanding of the relationship between organizations and individuals. In fact, our findings show that each dimension has a relational dynamic that can be understood in terms of exchange. Table 2 presents for each dimension the types of exchange that have been identified and how they unfold on Internet and social media.

Table 2. A relational approach to membership

\section{Organizations Individuals}

\section{Membership as resource}

Exchange Organizations get fees

On Internet and social Members can be recruited media
Individuals get support, benefits and services

Support and information on benefits and services can be given

Membership as representativeness

Exchange Organizations get legitimacy

On Internet and social media
Likes and followers can "count" in the numbers' game of representation
Members get a voice in collective bargaining and politics

The organizations' norms, values and policy-positions are communicated and negotiated.

\section{Membership as participation}

Exchange

On Internet and social media
Organizations get members to perform organizational tasks
Members shape organizational strategies

Organizational tasks are promoted

Membership as identity

Exchange

On Internet and social media
Organizations get support for collective identities

Collective identities can be fostered
Members get a collective identity

Collective identity can be negotiated and challenged 
As previously discussed, we also found an interesting overlap between the dimensions. For instance, fostering participation can be seen as a way of transforming passive members into active members, which provides the organization with more resources, in terms not only of fees but also of engagement. Furthermore, identity-claims by members can be seen as part of being represented by the union. While we have applied the framework for exploring membership in trade unions, the framework should be useful in any study of membership in social movements, interest groups, or civil society organizations, provided that they organize in an associational form.

One of the strengths of the framework is that it potentially allows us to see relational dynamics between organizations and individuals that go beyond formal membership. In fact, the unions seem only to a small extent occupied with assessing who is and who is not a formal member, when communicating on the Internet and on social media. The boundaries between members, adherents, constituencies, sympathizers, and a general public become blurred and social media in particular seem to allow communication with a group of individuals whose formal status in relation to the organization is unclear.

When it comes to membership as resource and as participation, Internet and social media seem to add another channel of communication without re-constituting or altering the understanding of membership. We find no support for a shift towards a broadening of the concept of membership as suggested by Karpf (2012). Internet and social media seem to provide an opportunity to strengthen traditional formal membership and engagement in the organization, without any replacements by "likes" and "followers".

Concerning representativeness and identity we find that the two-way channels of communication offered by Internet and social media might challenge traditional processes of representation and identity construction. Digitalization seems to provide members with a new, more direct channel of communication with the unions, something the organizations need to handle. Traditional hierarchical structures of representation are challenged and so are institutionalized collective identities and potentially ideological orientations as well. This is consistent with the inclusion-exclusion paradox discussed in previous research (Solebello et al. 2016). While one of the unions seems to be able to use Internet and social media as a means to be more inclusive without sparking conflicts, the other struggles more with this paradox. Perhaps because it is experiencing an ideological shift in parts of its traditional membership base, the conflict becomes more evident and Internet and social media are used both to keep a dialogue open and hence be inclusive but also to state the core value and normative character of the organization and hence be exclusive. The use of Internet and social media does not seem to bring forth an alteration or re-constitution of membership as such.

From the perspective of the societal changes brought about by digitalization and its impact on trade unions, we would argue that organizations are not monolithic actors, and they are always in transition. Organization requires constant organizing and part of these processes is adapting to new technologies. The introduction of new communication technologies creates opportunities in the sense that it makes new 
arenas available to membership-related activities, whether they are related to resources, representativeness, participation, or identity. The use of these communication technologies might, however, clash with institutionalized ways of organizing, i.e. with organizational technologies. This happens, for instance, when communication technologies bring visibility to identities that clash with institutionalized collective identities or when recruiting tends to overshadow organizing. All in all, Swedish trade unions do not seem to be adapting to new technologies, they rather use them as opportunities for strengthening and reviving traditional forms of membership. This might also be due to the fact that Swedish trade unions still hold a strong position on the labor market and in civil society and hence find fewer incentives to re-formulate the premises of membership in the digital era.

\section{Funding}

This work was supported by the Swedish Research Council for Health, Working Life and Welfare (FORTE; Grant number: 2015-00038).

\section{References}

Ahrne, G. \& N. Brunsson (2011) "Organization outside organizations: The significance of partial organization", Organization 18 (1):83-104. https://doi. org/10.1177/1350508410376256

Ahrne, G. (1994) Social organizations: Interaction inside, outside and between organizations. London: Sage.

Akademikerförbundet SSR (2017) "Förbundet", https://akademssr.se/om-oss (accessed 17 August 2017).

Baer, D. (2007) "Voluntary association involvement in comparative perspective", 67-125 in L. Trägårdh (Ed.) State and civil society in Northern Europe - the Swedish model reconsidered. New York: Berghahn Books. https://doi.org/10.2307/j. ctt1x76dkp.10

Baer, D., J. Curtis \& E. Grabb (2001) "Has voluntary association activity declined? Cross-national analyses for fifteen countries", Canadian Review of Sociology/Revue Canadienne de Sociologie 38 (3):249-274. https://doi.org/10.1111/j.1755-618x.2001. tb00973.x

Bengtsson, E. (2013) "Swedish trade unions and European Union migrant workers", Journal of Industrial Relations 55 (2):174-189. https://doi.org/10.1177/0022185612473211

Bennett, L. \& A. Segerberg (2013) The logic of connective action: Digital media and the personalization of contentious politics. Cambridge: Cambridge University Press. https://doi.org/10.1017/CBO9781139198752.001

Bennett, L. \& A. Segerberg (2012) "The logic of connective action: Digital media and the personalization of contentious politics", Information, Communication \& Society 15 (5):739-768. https://doi.org/10.1080/1369118X.2012.670661

Björkman, H. \& T. Huzzard (2005) ”Membership interface unionism: A Swedish 
white-collar union in transition", Economic and Industrial Democracy 26 (1):65-88. https://doi.org/10.1177\%2F0143831X05049403

Boeri, T., A. Brugiavini \& L. Calmfors (2001) (Eds.) The role of unions in the twentyfirst century: A report for the Fondazione Rodolfo Debenedetti. Lanham MD: Oxford University Press. http://dx.doi.org/10.1093/0199246580.001.0001

Bryson, A., R. Gomez \& P. Willman (2010) "Online social networking and trade union membership: What the Facebook phenomenon truly means for labor organizers", Labor History 51 (1):41-53. https://doi.org/10.1080/00236561003654719

Casey, J. (2004) "Third sector participation in the policy process: A framework for comparative analysis", Policy \& Politics 32 (2):241-257. https://doi. org/10.1332/030557304773558170

Chaison, G. (2005) "The dark side of information technology for unions", The Journal of Labor and Society 8 (4):395-402. https://doi.org/10.1111/j.17434580.2005.00025.x

Diamond, W.J. \& R.B. Freeman (2002) "Will unionism prosper in cyberspace? The promise of the Internet for employee organization", British Journal of Industrial Relations 40 (3):569-596. https://doi.org/10.1111/1467-8543.00247

Dür, A. \& G. Mateo (2012) "Who lobbies the European Union? National interest groups in a multilevel polity", Journal of European Public Policy 19 (7):969-987. https://doi.org/10.1080/13501763.2012.672103

Einarsson, S. (2011) "The revitalization of a popular movement: Case study research from Sweden", Voluntas 22 (4):658-681. https://doi.org/10.1007/s11266-011-9208-2

Einarsson, T. (2012) Membership and organizational governance. Stockholm: Stockholm School of Economics.

Fantasia, R., K. Voss \& B. Eidlin (2013) "Labor movement”, in D.A. Snow, D. della Porta, B. Klandermans \& D. McAdam (Eds.) The Wiley-Blackwell encyclopedia of social and political movements. Chichester, UK: Wiley-Blackwell. https://doi. org/10.1002/9780470674871.wbespm452

Frangi, L. \& M. Barisione (2015) "A Are you a union member?' Determinants and trends of subjective union membership in Italian society (1972-2013)", Transfer, The European Review of Labour and Research 21 (4):451-469. https://doi. org/10.1177/1024258915602635

Greer, C.S. (2002) "E-Voice: How information technology is shaping life within unions", Journal of Labor Research 23 (2):215-235. https://doi.org/10.1007/s12122002-1003-9

Gumbrell-McCormick, R. \& R. Hyman (2013) Trade unions in Western Europe: Hard times, hard choices. Oxford: Oxford University Press. https://doi.org/10.1093/acpro f:oso/9780199644414.001.0001

Hunt, A.S. \& D.R. Benford (2007) "Collective identity, solidarity and commitment", 433-457 in D.A. Snow, S.A. Soule \& H. Kriesi (Eds.) The Blackwell companion to social movements. Malden MA: Blackwell Publishing. https://doi. org/10.1002/9780470999103.ch19

Hvenmark, J. (2008) Reconsidering membership: A study of individual members' formal 
affiliation with democratically governed federations. PhD dissertation. Stockholm: Stockholm School of Economics.

Hyman, R. (2004) "Is industrial relations always ethnocentric?", 265-292 in B.E. Kaufman (Ed.) Theoretical perspectives on work and the employment relationship. Champaign IL: Industrial Relations Research Association.

IF Metall (2017) "Om oss", https://www.ifmetall.se/om-oss/ (accessed 17 August 2017). Johansson, H. \& G. Scaramuzzino (2019) "The logics of digital advocacy: Between acts of political influence and presence", New Media \& Society 21 (7):1528-1545. https://doi.org/10.1177/1461444818822488

Karpf, D. (2012) The MoveOn effect: The unexpected transformation of American political advocacy. New York: Oxford University Press. https:/doi.org/10.1093/acprof: oso/9780199898367.001.0001

Kjellberg, A. (2019) "Den svenska partsmodellen utmanad: Facket, arbetsgivarna och lönebildningen", 119-148 in Å. Sandberg (Ed.) Arbete och välfärd: Ledning, personal och organisationsmodeller i Sverige. Lund: Studentlitteratur.

Kjellberg, A. (2011) "The decline in Swedish union density since 2007". Nordic Journal of Working Life Studies 1 (1):67-93. https://doi.org/10.19154/njwls.vli1.2336

Kjellberg, A. (2009) "Fackliga relationer och industriella relationer", 241-283 in T. Berglund \& S. Schedin (Eds.) Arbetslivet. Lund: Studentlitteratur.

Klandermans, B. \& M. De Weerd (2000) "Group identification and political protest", 68-90 in S. Stryker, T.J. Owens \& R.W. White (Eds.) Self, identity, and social movements. Minneapolis: University of Minnesota Press.

Klüver, H. (2010) "Europeanization of lobbying activities: When national interest groups spill over to the European level", Journal of European Integration 32 (2):175191. https://doi.org/10.1080/07036330903486037

Kozinets, R.V. (2010) Netnography: Doing ethnographic research online. Los Angeles: SAGE.

Köhler, H.D. \& J.P. Calleja Jiménez (2012) "Transformations in Spanish trade union membership", Industrial Relations Journal 43 (3):281-292. https://doi.org/10.1111/ j.1468-2338.2012.00678.x

Lehndorff, S., H. Dribbusch, \& T. Schulten (2017) "European trade unions in a time of crises: An overview", 7-35 in S. Lehndorff, H. Dribbusch, \& T. Schulten (Eds.) Rough waters: European trade unions in a time of crises. Brussels: European Trade Union Institute (ETUI aisbl).

Lundström, T. \& L. Svedberg (2003) "The voluntary sector in a social democratic welfare state: The case of Sweden", Journal of Social Policy 32 (2):217-238. https:// doi.org/10.1017/s0047279402007006

Mackerle-Bixa, S., M. Meyer \& G. Strunk (2009) "Membership and participation: School of democracy or hideaway of biedermeier?", Journal of Civil Society 5 (3):243263. https://doi.org/10.1080/17448680903351776

McCarthy, J. \& M. Zald (1977) "Resource mobilization and social movements: A partial theory", American Journal of Sociology 82 (6):1212-1241. https://doi. org/10.1086/226464 
Michels, R. (2001) Political parties: A sociological study of the oligarchical tendencies of modern democracy. Kitchener: Batoche Books.

Minkoff, D. (2016) "The payoffs of organizational membership for political activism in established democracies", American Journal of Sociology 122 (2):425-468. https:// doi.org/10.1086/687743

Movitz, F. \& Å. Sandberg (2019) "Arbetsliv i Sverige: Modell i förändring”, 77-118 in A. Sandberg (Ed.) Arbete och välfärd: Ledning, personal och organisationsmodeller $i$ Sverige. Lund: Studentlitteratur.

Oliver, P. (2013) "Collective action (collective behavior)", in D.A. Snow, D. della Porta, B. Klandermans \& D. McAdam (Eds.) The Wiley-Blackwell encyclopedia of social and political movements. Chichester: Wiley-Blackwell. https://doi. org/10.1002/9780470674871.wbespm032

Palm, J. (2017) There is power in a union: Trade union organization, union membership and union activity in Sweden. PhD dissertation. Stockholm: Department of Sociology, Stockholm University.

Panagiotopoulos, P. (2012) "Towards unions 2.0: Rethinking the audience of social media engagement", New Technology, Work \& Employment 27 (3):178-192. https:// doi.org/10.1111/j.1468-005x.2012.00287.x

Panagiotopoulos, P. \& J. Barnett (2015) "Social media in union communications: An international study with UNI Global union affiliates", British Journal of Industrial Relations 53 (3):508-532. https://doi.org/10.1111/bjir.12060

Putnam, R.D. (2001) Bowling alone: The collapse and revival of American community. London: Simon \& Schuster.

Rego, R., P. Marques Alves, R. Naumann, \& J. Silva (2014) "A typology of trade union websites with evidence from Portugal and Britain", European Journal of industrial Relations 20 (2):185-195. https://doi.org/10.1177/0959680113516405

Scaramuzzino, G. \& A. Meeuwisse (2019) "Socialarbetares protester genom nätverk på sociala medier", Socionomens forskningssupplement 45 (1):4-17.

Scaramuzzino, G. (2017) "Att höja sin röst: Socialarbetares mobilisering och organisering genom sociala medier", 201-224 in S. Linde \& R. Scaramuzzino (Eds.) Socialt arbete i civilsambället: Aktörer, former och funktioner. Lund: Studentlitteratur.

Scaramuzzino, G. (2014) "Sexsäljares och sexköpares kollektiva handlande på internet: En svensk 'Fuckförening'?”, PhD dissertation. Växjö: Linnaeus University Press.

Scaramuzzino, R. \& M. Wennerhag (2013) "Influencing politics, politicians and bureaucrats: Explaining differences between Swedish CSOs' strategies to promote political and social change". Paper presented at the 7th ECPR General Conference, https://ecpr.eu/Filestore/PaperProposal/59ca8540-c4ab-48ce-a033-26a969c7cfb0. pdf (accessed 1 April 2020).

Schradie, J. (2015) "Political ideology, social media and labor unions: Using the Internet to reach the powerful, not mobilize the powerless", International Journal of Communication 9: 1985-2006.

Shirky, C. (2008) Here comes everybody: The power of organizing without organizations. New York: Penguin Books. https://doi.org/10.1109/mspec.2008.4607925 
Sipp, K. (2016) "The Internet versus the labor movement: Why unions are latecomers to digital organizing", New Labor Forum 25 (2):88-92. https://doi. org/10.1177/1095796016639277

Solebello, N., M. Tscjrhart \& J. Leiter (2016) "The paradox of inclusion and exclusion in membership associations", Human Relations 69 (2):439-460. https://doi. org/10.1177/0018726715590166

Stevens, C. \& C. Greer (2005) "E-voice, the Internet, and life within unions: Riding the learning curve", Working USA 8 (4):439-455. https://doi.org/10.1111/j.17434580.2005.00028.x

Strøby Jensen, C. (2017) "Political attitudes and trade union membership in the Nordic countries", European Journal of Industrial Relations 23 (4):381-395. https://doi. org/10.1177/0959680117708372

Tilly, C. (1984) "Social movements and national politics", 297-313 in C. Bright \& S. Harding (Eds.) Statemaking and social movements. Ann Arbor: University of Michigan Press.

van Stekelenburg, J. (2013) "Collective identity", in D. Snow, D. della Porta, B. Klandermans \& D. McAdam (Eds.) The Wiley-Blackwell encyclopedia of social and political movements. Chichester, UK: Wiley-Blackwell. https://doi. org/10.1002/9780470674871.wbespm039

Voss, K. \& R. Sherman (2000) "Breaking the iron law of oligarchy: Union revitalization in the American labor movement", American Journal of Sociology 106 (2):303-349. https://doi.org/10.1086/316963

Waddington, J. (2015) "Trade union membership retention in Europe: The challenge of difficult times", European Journal of Industrial Relations 21 (3):205-221. https:// doi.org/10.1177/0959680114538708

Ward, S. \& W. Lusoli (2003) "Dinosaurs in cyberspace? British trade unions and the Internet", European Journal of Communication 18 (2):147-179. https://doi.org/10.1 177/0267323103018002001

Western, B. (1995) "A comparative study of working-class disorganization: Union decline in eighteen advanced capitalist countries", American Sociological Review 60 (2):179-201. https://doi.org/10.2307/2096383

\section{Authors}

Gabriella Scaramuzzino's research interests concern how the use of social media affects civil society, i.e. mobilization, organization, membership, advocacy, engagement and resources. In an ongoing research project, she explores how the fear of being exposed to hate, threats and harassment affects civil society and what impact the use of social media has in these processes.

Roberto Scaramuzzino's research interests include changes in the welfare and integration system and the role of civil society organizations, their resources, advocacy activities and collaboration with public authorities. He is currently working in a 
research program on civil society elites focusing on leaders and power concentration in civil society.

\section{Corresponding author}

Gabriella Scaramuzzino

School of Social Work, Lund University, Box 23, 22100 Lund, Sweden gabriella.scaramuzzino@soch.lu.se 